\title{
Diversity of the Schizophoria lineage (Brachiopoda: Orthida) in the Lower and Middle Devonian of Poland and adjacent areas
}

\author{
Adam T. Halamski
}

Received: 14 November 2011/ Accepted: 23 February 2012/Published online: 20 March 2012

(C) The Author(s) 2012. This article is published with open access at Springerlink.com

\begin{abstract}
The nominative subgenus of Schizophoria (Brachiopoda, Orthida) is represented in the Lower and Middle Devonian of Poland and of the western Ukraine by six taxa: late Emsian Schizophoria (S.) interstrialis, late Eifelian S. (S.) schnuri biscissa, early Givetian S. (S.) schnuri schnuri, middle to late Givetian $S$. (S.) schnuri prohibita ssp.n., middle Givetian $S$. (S.) parvaepunctata and late Givetian $S$. (S.) sp.n. (unnamed for lack of sufficient material). Morphotypes referable to $S$. (S.) schnuri biscissa and to $S$. (S.) schnuri junkerbergiana co-occur in the same outcrop (not necessarily in the same levels), wherefore the separation of these subspecies may be maintained only if they are considered as chronosubspecies (unverifiable on the studied material) but not as geographic variants (hypothesis falsified by the studied material). A lectotype for $S$. (S.) interstrialis and a neotype for $S$. (S.) parvaepunctata are selected. Punctae diameter and density (either an important systematic character according to some authors or devoid of such value according to other ones) were investigated: they show important within-individual and within-sample variation, wherefore they cannot serve to distinguish related species. On the contrary, punctae character combinations are sufficiently constant to help differentiate subgenera or groups of species. In the studied material, three clusters are distinguished on the basis of the punctae characteristics: S. (Pachyschizophoria) and $S$. (S.) parvaepunctata differ between each other and from all other investigated species of S. (Schizophoria); the
\end{abstract}

\footnotetext{
A. T. Halamski $(\square)$

Polish Academy of Sciences,

Institute of Paleobiology,

Twarda 51/55, 00-818 Warszawa,

Poland

e-mail: ath@twarda.pan.pl
}

latter are indistinguishable on the sole basis of punctae characteristics.

Keywords Brachiopoda - Orthida - Schizophoria . Holy Cross Mountains · Volhynia · Middle Devonian · Taxonomy $\cdot$ Punctae distribution

Kurzfassung Die nominative Untergattung von Schizophoria (Brachiopoda, Orthida) ist im Unter- und Mitteldevon Polens und der westlichen Ukraine durch sechs Taxa vertreten: Schizophoria (S.) interstrialis aus dem oberen Emsium, Schizophoria (S.) schnuri biscissa aus dem oberen Eifelium, S. (S.) schnuri schnuri aus dem unteren Givetium, $S$. (S.) schnuri prohibita ssp.n. aus dem mittleren bis oberen Givetium, $S$. (S.) parvaepunctata aus dem mittleren Givetium, und $S$. (S.) sp.n. (nicht benannt wegen des nicht ausreichendes Material) aus dem späten Givetium. Die zu S. (S.) schnuri biscissa und $S$. (S.) schnuri junkerbergiana beziehenden Morphotypi kommen zusammen an derselben Lokalität vor (aber nicht notwendigerweise in demselben Stratum), darum können sie nur als Chronosubspecies (nicht belegbar nach dem untersuchten Material) unterschieden werden, aber nicht als geographische Varianten (Hypothese widerlegt nach dem untersuchten Material). Ein Lectotypus für $S$. $(S$.) interstrialis und ein Neotypus für $S$. (S.) parvaepunctata werden ausgewählt. Der Durchmesser und die Dichte der Poren (nach einigen Autoren ein gutes taxonomisches Merkmal und nach anderen nicht), werden untersucht: Die Variation innerhalb eines Individuums und einer Probe ist bedeutend, darum kann sie nicht benutzen werden, um die verwandte Arten zu unterscheiden. Im Gegenteil, Porenmerkmalekombinationen sind genügend fest, darum kann sie helfen, um die Untergattungen oder die Artgruppen zu unterscheiden. In dem untersuchten Material 
werden drei Gruppen nach Porenmerkmale unterschieden: $S$. (Pachyschizophoria) und S. (S.) parvaepunctata unterscheiden sich voneinander und von den übrigen untersuchten Arten von $S$. (Schizophoria); diese können allein den Porenmerkmale unterschieden werden.

Schlüsselwörter Brachiopoda - Orthida - Schizophoria . Heiligkreuzgebirge · Volhynien · Mitteldevon · Taxonomie · Porenverteilung

\section{Introduction}

Schizophoria (Brachiopoda, Orthida) is a cosmopolitan genus of long stratigraphic range (Upper Silurian to Lower Carboniferous). The aim of the present paper is to give a systematic account of the Lower and Middle Devonian representatives of its nominative subgenus from Poland and western Ukraine (the acme interval of its diversity in these areas). This allows to confirm the existence of an evolutionary lineage previously described from the Eifelian to lower Givetian of the Eifel and to find its continuation (Schizophoria schnuri prohibita ssp.n.) in the middle to upper Givetian. Moreover, the validity of the punctae distribution as a systematic criterion, either an important systematic character according to some authors or devoid of such value according to other ones, is assessed.

\section{Geological setting}

The investigated material comes from the Lower and Middle Devonian strata cropping out in two geographic regions: the Holy Cross Mountains (Góry Świętokrzyskie) in central Poland and the Povcha-Mizoch (Pełcza-Mizocz) ${ }^{1}$ Range (Povcha Upland according to other authors) in Volhynia (western Ukraine; Fig. 1).

The Holy Cross Mountains belong to the Middle Polish Anticlinorium and form a Palaeozoic horst that can be further subdivided into two regions (Stupnicka 1992 and references therein), Łysogóry (or Northern) and Kielce (or Southern; north and south of the Holy Cross Dislocation, respectively, Fig. 1B). Fossil faunas of the two regions are notably different. Stratigraphic details for the Middle Devonian of the Northern Region are to be found in Halamski (2005 and references therein) and Halamski and Racki (2005). Orthide brachiopods were monographed by Biernat (1959) and Halamski (2009). Stratigraphic details for the Middle Devonian of the southern region and the Lower Devonian of both

\footnotetext{
${ }^{1}$ Ukrainian toponyms are transcripted according to the Ukrainian National Transliteration standard. Polish equivalents (official before 1939) are given in parentheses.
}

regions are to be found in Racki (1993a, 2005) and Halamski and Racki (2005). Brachiopods from the Kielce Region were described by Racki (1993b).

Late Emsian to earliest Eifelian Grzegorzowice Formation and late Eifelian to early Givetian Skały beds crop out in several sections belonging to the Bodzentyn Syncline situated in the Łysogóry Region. Late Emsian limestones and marls crop out near Grzegorzowice (Pajchlowa 1957; Malec 1999) and yielded Schizophoria (S.) interstrialis Biernat, 1954. Late Eifelian ('Freilingian') brachiopod shales are known from a famous outcrop at Skały known informally as the 'fundamental (or brachiopod) pit' (73 sensu Pajchlowa 1957; brachiopod shales sensu Biernat 1959; SK-3 sensu Halamski 2009; faunistic list given by Halamski and Zapalski 2006). It yielded a rich collection of Schizophoria (S.) schnuri biscissa Struve, 1965. A younger, early Givetian level with Schizophoria (S.) schnuri schnuri Struve, 1965 crops out at Błonia Sierżawskie near Świętomarz (outcrop SW-2 sensu Halamski 2009; stratigraphy discussed by Halamski and Segit 2006). A roughly coeval level with the same species was encountered in a well in Włochy near Skały.

Middle to late Givetian Laskowa Góra Beds (set A sensu Racki 1993a) crop out in the eastern wall of the Józefka quarry (formerly Józefka Hill) at Górno (Radlin Syncline, a subordinate element of the Kielce-Łagów Synclinorium, Kielce Region). Schizophoria (S.) schnuri prohibita ssp.n. is accompanied by several species of brachiopods (representatives of Pugnacidae, Hypothyridinidae, Reticulariidae, Atrypida and possibly Cyrtospiriferidae; Baliński and Halamski, unpublished data), as well as crinoids and rarer corals, bivalves and orthocone nautiloids. Conodont assemblages indicate an interval between Middle varcus and disparilis Zones (Racki, unpublished data). Approximately coeval rocks were cropping out in the southern part of a trench dug along the road from Górno to Daleszyce about $100 \mathrm{~m}$ east from the above-mentioned locality; at present, only the northern part of the trench showing the Frasnian part of the section is accessible. This trench corresponds to outcrop V sensu Małkowski (1981) and to the type outcrop of Biernatella lentiformis Baliński, 1995 (Baliński 1995b). Approximately coeval strata crop out also in Laskowa (in geological papers this locality is most often incorrectly reported as Laskowa Góra) near Kielce.

Late Givetian Chęciny Beds cropping out at the eastern hill in Trzemoszna (south-east from Daleszyce, GałęziceBolechowice Syncline, Kielce Region) yielded three poorly preserved specimens of Schizophoria (S.) sp.n. (S. aff. macfarlanei sensu Racki 1993b).

The Middle Devonian of Volhynia is known from two isolated outcrops in the vicinity of Povcha (Pełcza) (von Kelus 1939; Samsonowicz 1950; Fig. 1C). Givetian deposits surrounded by a continuous Cretaceous and Neogene cover cropped out (localities inaccessible at present; D. Drygant, 


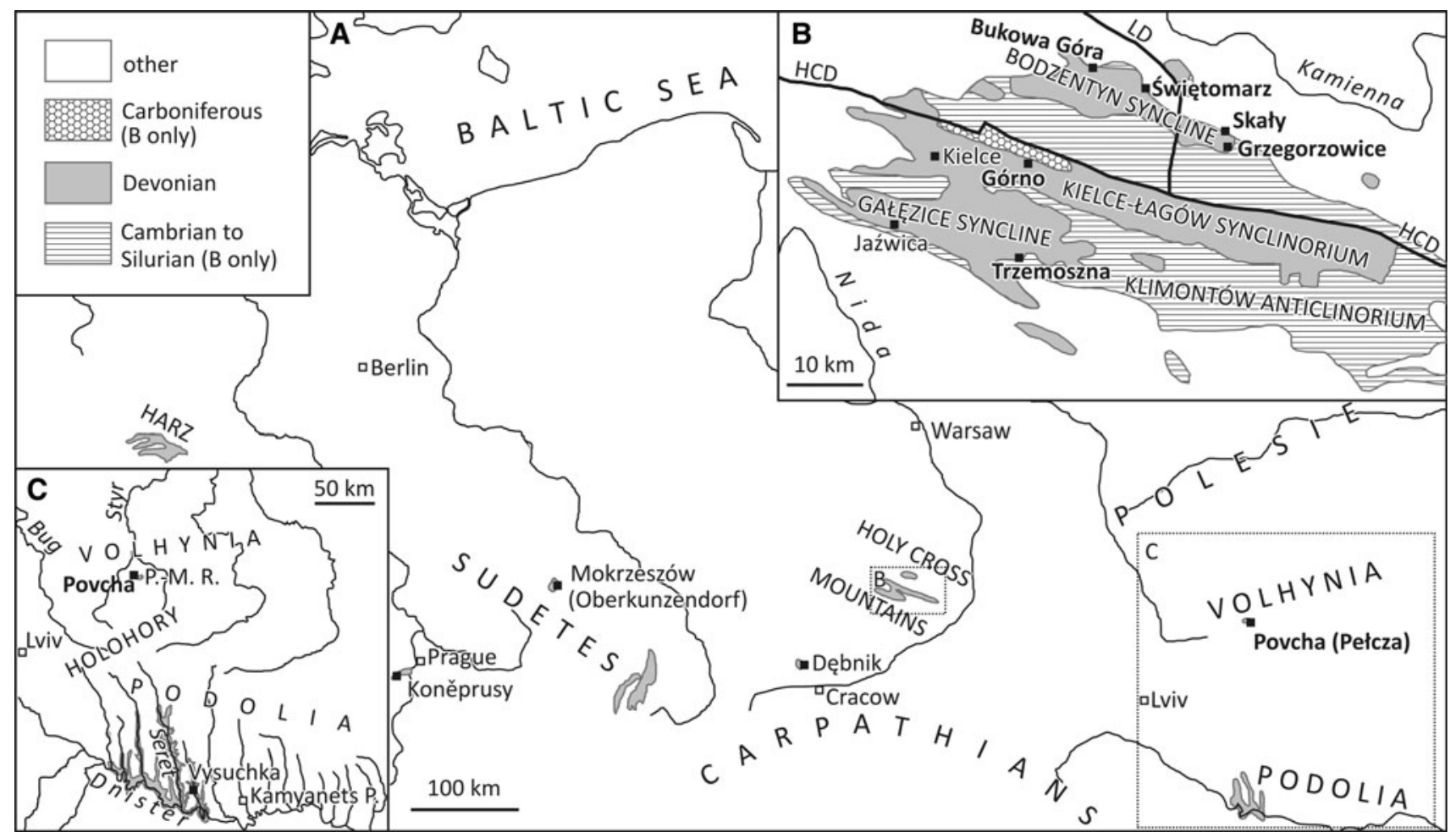

Fig. 1 Geographic and geologic setting of the studied fauna. $A$ Topography of central Europe and localisation of Devonian outcrops. $B$ Geologic map of the Palaeozoic core of the Holy Cross Mountains. $C$ Topography of Podolia and Volhynia and localisation of Devonian outcrops. Hollow squares major cities. Black squares Devonian localities either discussed (in boldface) or mentioned (in

pers. comm. 2010) at Biła Debra near Tartak and at Kamieniarnia (Samsonowicz 1950: fig. 1). They have been dated to the Middle Givetian (Middle varcus Zone; Drygant 2010) and yielded Schizophoria (S.) parvaepunctata von Kelus, 1939 accompanied by numerous other brachiopods, e.g. Diazoma volhynica (von Kelus, 1939) and Desquamatia parazonata (von Kelus, 1939).

\section{Systematic part}

Institutional abbreviations: GIUS, Geological Institute of the Silesian University, Sosnowiec, Poland; MWG, Museum of the Faculty of Geology, Warsaw University, Warsaw, Poland; ZPAL, Institute of Paleobiology, Polish Academy of Sciences, Warsaw, Poland.

Phylum Brachiopoda Duméril, 1805 ('1806') Subphylum Rhynchonelliformea Williams et al., 1996 Classis Rhynchonellata Williams et al., 1996 Order Orthida Schuchert \& Cooper, 1931 Family Schizophoriidae Schuchert \& LeVene, 1929 Genus Schizophoria King, 1850
Roman typeface) in the text. Rivers in italics. Present place names given first, former ones in parentheses. $H C D$ Holy Cross Dislocation, $L D$ Łysogóry Dislocation, P.-M. R. Povcha-Mizoch Range. Redrawn and modified after Dupret and Blieck (2009), von Gaertner and Walther (1971), Kozłowski (1929), Nikiforova et al. (1985) and Samsonowicz $(1950,1966)$

Type species: Conchyliolithes Anomites resupinatus Martin, 1809.

Diagnosis: see Jansen (2001).

Remarks: The present paper is limited to the Lower and Middle Devonian representatives of the subgenus S. (Schizophoria) for the following reasons. First, in Poland and adjacent areas only two Devonian taxa not belonging to the nominative subgenus of Schizophoria have been found up to now: S. (Eoschizophoria) fragilis Kozłowski, 1929 from the Zlichovian of Podolia (type locality: Vysuchka) was described in detail by Kozłowski (1929) and by Nikiforova et al. (1985), whereas the material of S. vulvaria (von Schlotheim, 1820), S. aff. vulvaria (von Schlotheim, 1820) and S. striatula (von Schlotheim, 1820), all three sensu Łobanowski (1971) (possibly a single species belonging to Pachyschizophoria on account of the slender shape of the ventral muscle field and the convexly curved brachiophore plates; U. Jansen, pers. comm. 2012), from the upper Emsian of Bukowa Góra (northern region of the Holy Cross Mts.) was not available for restudy. Moreover, the morphology, systematics and evolution of the subgenera 
S. (Pachyschizophoria) and S. (Rhenoschizophoria) were described in detail by Jansen (2001).

There exist two contrasting approaches to the taxonomy of Middle Devonian species of Schizophoria in Europe. Struve $(1963,1965)$ described the $S$. schnuri complex with five subspecies (both chronosubspecies and geographic variants); small representatives of the genus with different ornamentation were segregated as S. pygmaea, whereas S. striatula and S. excisa were restricted to their type samples from the Frasnian. On the contrary, Pocock (1966) merged S. striatula with $S$. schnuri except the subspecies S. schnuri blankenheimensis that she considered as conspecific to S. pygmaea on account on the existence of intermediary forms.

The facts observed in the Holy Cross Mountains incline the present author to prefer the former approach, although with some reservations. In effect, the general appearance of stratigraphically separated (Eifelian versus Givetian) samples of Schizophoria is strikingly different. Moreover, samples from a given level in the Holy Cross Mountains are remarkably similar to those from coeval levels of both the Holy Cross Mts. and the Eifel. Last, Schizophoria striatula is known only from its limited type material (from the Frasnian), wherefore its variability and internal structures are unknown; using this name for brachiopods of different (Middle Devonian) age will rather increase confusion than serve clarity. Middle Devonian reports of Schizophoria striatula (e.g. Baranov 2008) are herein considered doubtful.

Struve's approach is therefore followed with a large S. schnuri complex with several subspecies. S. pygmaea does not occur in Poland and will not be dealt with here. Following Jansen (2001: 17), subspecies are considered here as stratigraphically segregated populations differing by morphological trends rather than discrete characters (in which case they would have to be described as separate species). Consequently, such morphoclines arranged along chronoclines are observable only on large samples of adult individuals. On the contrary, the interpretation of certain samples as geographic variants (Struve 1965) is falsified (see below, under S. schnuri biscissa, for details).

Subgenus Schizophoria (Pachyschizophoria) Jansen, 2001

Type species: Hysteriolithes vulvarius von Schlotheim, 1820.

Diagnosis, species assigned: see Jansen (2001).

Remarks: Representatives of this subgenus do not occur in the studied material (but see above, under remarks on the genus Schizophoria). A Spanish taxon is described here solely for comparison of the punctae distribution.
Schizophoria (Pachyschizophoria) cf. vulvaria (von Schlotheim, 1820) (Fig. 8D, F)

Material: one specimen ZPAL 64/A from the upper Emsian of the Cabo la Vela section (La Ladrona Formation, Cantabrian Mts., Spain).

Description: Punctae in the central region of the shell ca. 15-45 $\mu \mathrm{m}$ in diameter, rather sparsely distributed, ca. 120 per $\mathrm{mm}^{2}$; in marginal region of remarkably different sizes, ca. 15-90 $\mu \mathrm{m}$ in diameter (Fig. 8D).

\section{Subgenus Schizophoria (Schizophoria) King, 1850}

Type species: as for the genus

Diagnosis: see Jansen (2001).

Remarks: According to Jansen (2001), the subgenus $S$. (Schizophoria) originated in the Lochkovian from an unidentified representative of the subgenus S. (Eoschizophoria). In the Lower Devonian the former subgenus is represented by the $S$. praecursor group (a single species, $S$. interstrialis, in the described material) and an offline, namely S. antiqua (the opinion of Pocock 1966 on the presence of this taxon in the Frasnian seems doubtful). The group of $S$. schnuri, descending from the $S$. praecursor group (Jansen 2001), is abundant in the Middle Devonian (see below). Other Middle Devonian taxa include (among others, see Stigall Rode 2005 for a detailed list of taxa from the USA) $S$. parvaepunctata (see below) as well as solely North American S. macfarlanei (Meek, 1868), S. ferronensis Imbrie, 1959 and S. mesacarina Imbrie, 1959, and finally S. traversensis Grabau, 1931, S. excellens Grabau, 1931 and several other taxa of uncertain status from South China (Grabau 1931-33). A further continuation of the evolutionary line of $S$. praecursor-S. schnuri may be found in the Upper Devonian and is most probably represented by the lower Frasnian taxa described from the Russian Platform (S. kremsi Ljaschenko, 1959, S. uchtensis Ljaschenko, 1959 and others; Ljaschenko 1959). The specimen from the Barvaux Formation (Frasnian, Belgium) figured by Mottequin (2008: fig. 22F-J) under the name Schizophoria gr. striatula may also belong to this group, whereas the other putatively conspecific one from the Grand Breux Fm. (Frasnian, Belgium: Mottequin 2008: fig. 22A-E) does probably not. The widely used name S. striatula relates, in fact, to a single, poorly located specimen of dubious affinities (Struve 1965). The Upper Devonian representatives of Schizophoria in Poland are known from three groups of localities: Dębnik Anticline near Cracow (Baliński 1995a, 2002, 2006); Mokrzeszów (Oberkunzendorf) and other localities in the Świebodzice (Freiberg in Schlesien) Depression in the Sudetes (Dames 1868; Gunia 1968); last, Jaźwica and Kadzielnia quarry in 
Kielce (southern region of the Holy Cross Mountains; Racki 1993b). They are infrequent and usually poorly preserved, wherefore an inquiry upon the younger members of the discussed lineage has not been attempted.

Schizophoria (Schizophoria) interstrialis Biernat, 1954 (Figs. 2K-Y; 4D, I-K, P-R; 8E)

$\mathrm{v}^{*} 1954$ Schizophoria interstrialis n. sp.-Biernat, p. 496-499, text-figs. 5-7, pl. 1: 1-4

Type material: Biernat (1954) stated that 'the specimen' illustrated in pl. 1: 1-4 and text-figs. 5-7 is the holotype. In fact, six different specimens (syntypes) are concerned. The specimen ZPAL Bp I/2/1 (new number, material unnumbered in the original work) represented by Biernat (1954, pl. 1: 1-4) and in the present paper (Fig. 2P-T) is selected herein as the lectotype. The paralectotypes ZPAL Bp I/2/ 2-5 are illustrated herein in Fig. 4D, I-K, P-R.

Material: Four subcomplete specimens, one fragmentary dorsal valve, seven internal moulds of ventral valves and about 20 fragmentary and/or crushed shells, collection number ZPAL Bp $\mathrm{I} / 2$, all from the late Emsian Grzegorzowice Formation in Grzegorzowice.

Description: Shell medium-sized (up to $31 \mathrm{~mm}$ in width), transverse, dorsibiconvex, subelliptic in outline.

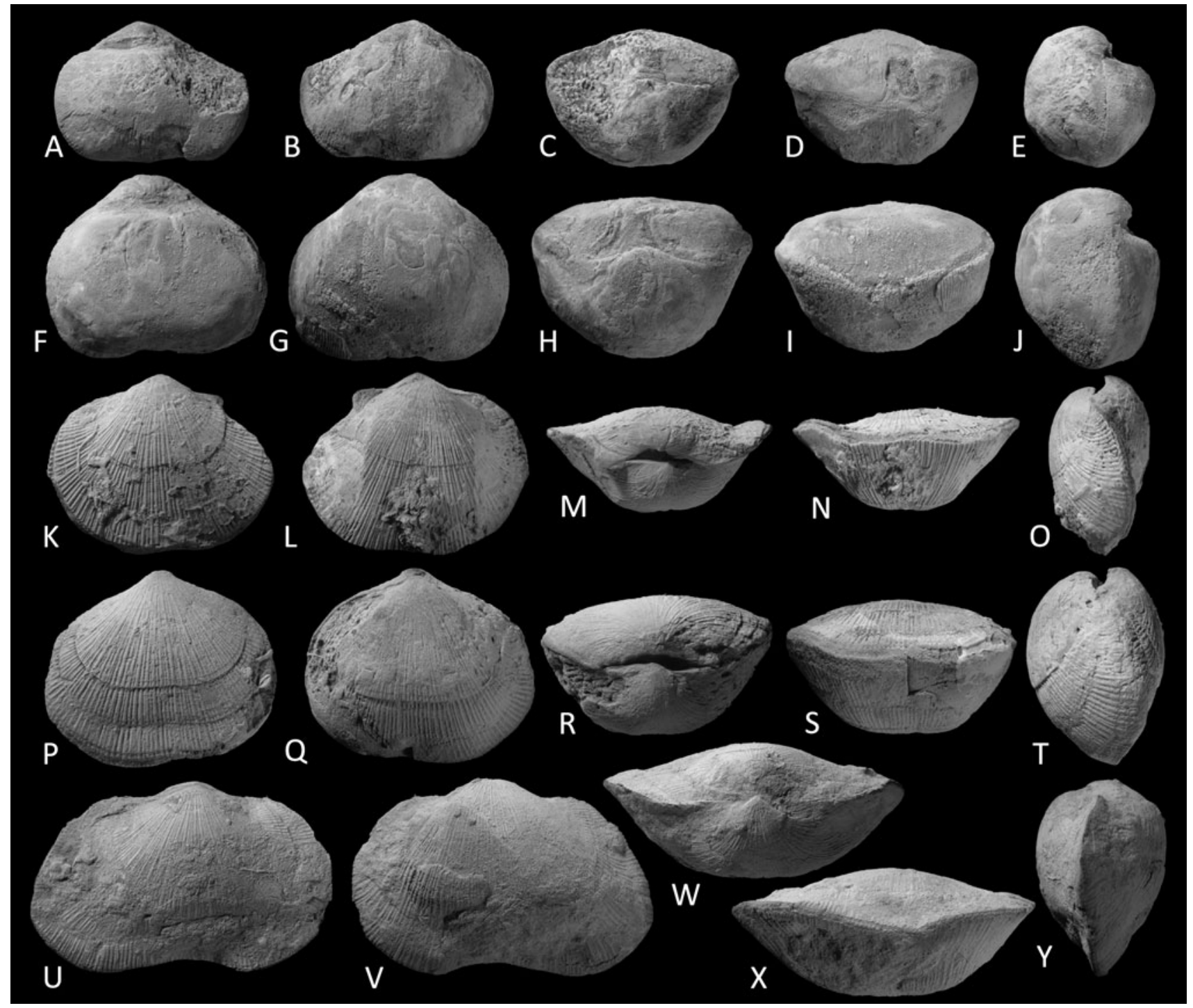

Fig. 2 External morphology of Schizophoria (Schizophoria). Articulated shells in dorsal, ventral, posterior, anterior and lateral views. All specimens shown $\times 1.5$. A-J Schizophoria $(S$.) sp.n. Trzemoszna, eastern hill, rubble; Chęciny Beds, upper Givetian. A-E Specimen GIUS 4/219/S-2. F-J Specimen GIUS 4/219/S-1; figured by Racki (1993b: fig. 1H, I). K-Y Schizophoria (S.) interstrialis Biernat, 1954. Grzegorzowice; Grzegorzowice Formation, upper Emsian. $K-O$ Lectotype ZPAL Bp IV/2/1. $P-T$ Specimen ZPAL Bp IV/2/6. $U-Y$ Specimen ZPAL Bp 64/3/1 
Maximal width about midlength of the shell, sometimes slightly more anteriorly. The width of the area usually about half the width of the shell. Anterior commissure either rectimarginate or with a very wide $(2 / 3-3 / 4$ of the shell width) and very shallow (dorsal) deflection. Dorsal valve strongly convex, slightly flattened medially in posterior region, more anteriorly with an incipient rather narrow sulcus; dorsal beak quite thick, markedly incurved. Dorsal interarea apsacline to orthocline. Ventral valve weakly convex. Ventral interarea apsacline.

Ornamentation parvicostellate. Costellae arising by intercalation, more seldom by bifurcation. In central region of both valves costellae are of very different thicknesses, while at anterior margin they are of about the same width, moderately coarse, 2-3 per mm. Growth lines usually not observed.

Dorsal interior. Cardinal process rather small, supported by a small shaft. Brachiophores not preserved. Dental sockets of moderate size. Posterior adductor scars parallel, narrow, separated by a broad and low median ridge. Anterior adductor scars diverging, separated by a much narrower median wall.

Ventral interior poorly preserved. Muscle field length up to half the valve length, its maximal width situated markedly anteriorly, length to width ratio 1:1-1.5:1.

Punctae medium-sized, ca. $20-30 \mu \mathrm{m}$ in diameter, distributed moderately densely, ca. 170 per $\mathrm{mm}^{2}$.

Remarks: The comparison of Schizophoria interstrialis with other representatives of the $S$. praecursor group is given in Table 1.

García-Alcalde (2001) listed a Schizophoria aff. interstrialis from the latest Emsian of the Cantabrian Zone, and Jansen (2001) reported a 'representative of the praecursor group' from the uppermost upper Emsian of the Dill Syncline (Kieselgallen-Schiefer). In both cases neither figures nor description were provided, so no inference on relationships of these taxa with the approximately coeval $S$. (S.) interstrialis is possible.
Fig. 3 External morphology of Schizophoria (Schizophoria), continued. Articulated shells in dorsal, ventral, posterior, anterior and lateral views. All specimens shown $\times 1.25$. A-O Schizophoria $(S$.) parvaepunctata von Kelus, 1939. Povcha (Pełcza) region, details unknown; Givetian. A-E Juvenile specimen MWG 02619/3. F-J Specimen MWG 02619/2. K-O Neotype MWG 02619/1. P-II Schizophoria (S.) schnuri biscissa Struve, 1965. Skały, 'fundamental pit'; Skały beds, upper Eifelian. $P-T$ Specimen ZPAL Bp 64/3/1. $U-Y$ Specimen ZPAL Bp 64/3/2. Z-DD Specimen ZPAL Bp 64/3/3. EE-II Specimen ZPAL Bp 64/3/4

\section{Schizophoria (Schizophoria) schnuri Struve, 1965}

Remarks: Various (partly unidentified at subspecific level) representatives of the S. schnuri complex were reported from the Eifel (Struve 1965), the Ardennes (Hubert et al. 2007), Holy Cross Mts. (Halamski 2009), Moravia (Havlíček 1977) and Burma (Anderson et al. 1969).

\section{Schizophoria (Schizophoria) schnuri biscissa Struve, 1965 (Figs. 3P-II; 4C, F-H, M-O; 8A)}

v. 2009 Schizophoria (Schizophoria) schnuri biscissa Struve, 1965-Halamski, p. 85-87, text-fig. 17, pls. 14: 1, 2, 12, 13, 18-20; 15: 1-10 [ubi syn.]

Material: several dozens of articulated shells, numerous separate dorsal and ventral valves from outcrop SK-3 sensu Halamski (2009), collection numbers ZPAL Bp IV and ZPAL 64/3.

Description: Morphology and anatomy, see Biernat (1959) and Halamski (2009).

Punctae medium-sized, ca. 13-27 $\mu \mathrm{m}$ in diameter, distributed moderately densely, ca. $215-400$ per $\mathrm{mm}^{2}$.

Remarks: Schizophoria schnuri biscissa differs from the following two subspecies of $S$. (S.) schnuri in its subtrapezoidal outline, the maximal width of the shell situated anteriorly and in slightly finer costellae $(2-4$ per $\mathrm{mm}$ at anterior margin compared with 2-3 in $S$. (S.) schnuri schnuri Struve, 1965 and S. schnuri prohibita subsp. nov.).

Table 1 Comparison of Early Devonian species of Schizophoria from central Europe

\begin{tabular}{llll}
\hline Taxon character & S. $($ S.) zephyrina (Barrande, 1879) & S. (S.) praecursor (Barrande, 1879) & S. (S.) interstrialis Biernat, 1954 \\
\hline Occurrence & Koněprusy Limestone, Bohemia (Pragian) & Grzegorzowice, Poland (upper Emsian) \\
Shape & Subequally biconvex & Dorsibiconvex & Strongly dorsibiconvex \\
Anterior commissure & Rectimarginate & Slightly deflected & Slightly deflected \\
Dorsal valve & Neither sulcus nor fold & A small convexity, not a true fold & Sulcus \\
Ornamentation & Costellae of subequal size & Slightly accentuated primaries & Slightly accentuated primaries \\
Characters given after & Havlíček (1977) & Havlíček (1977) & Present work \\
\hline
\end{tabular}




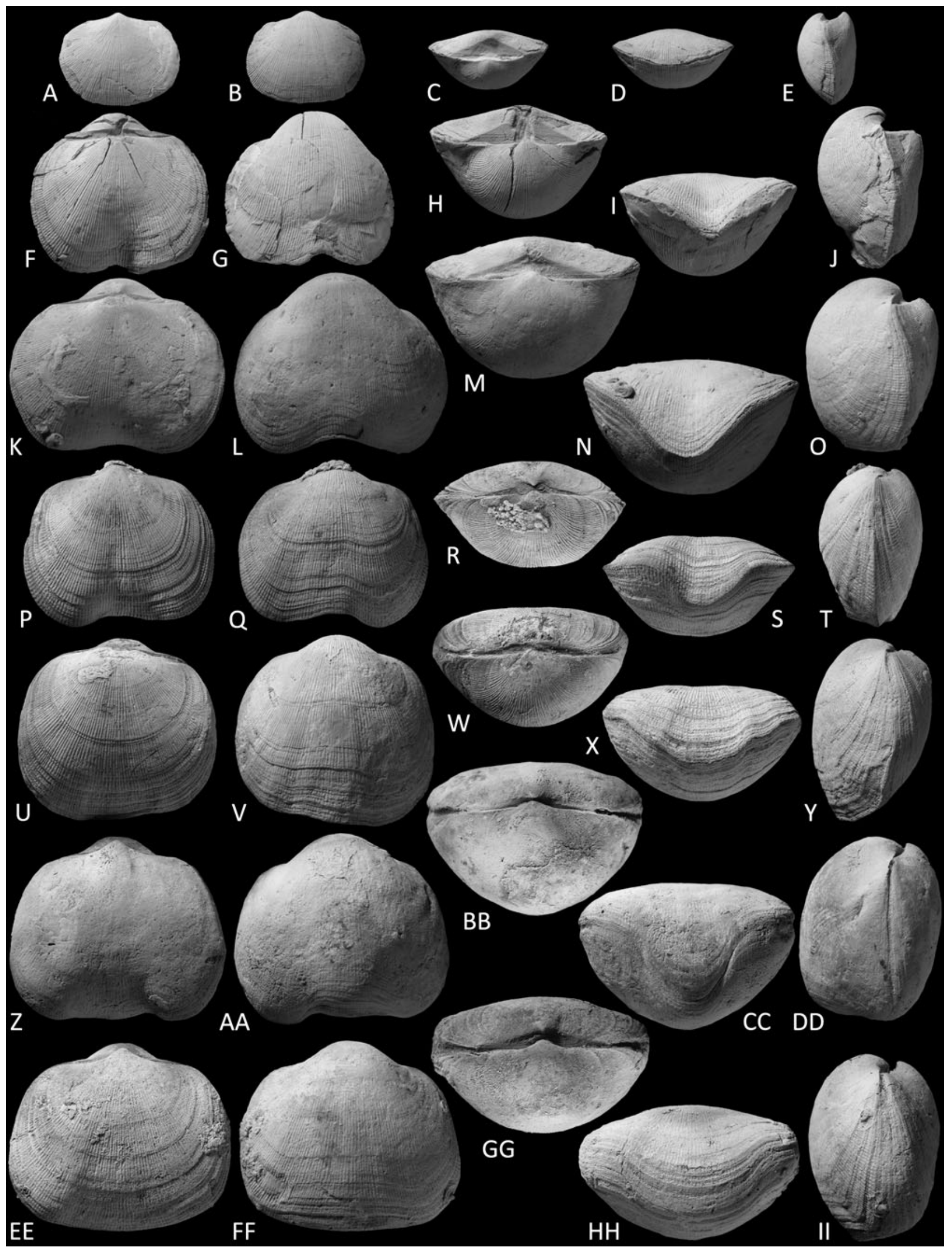




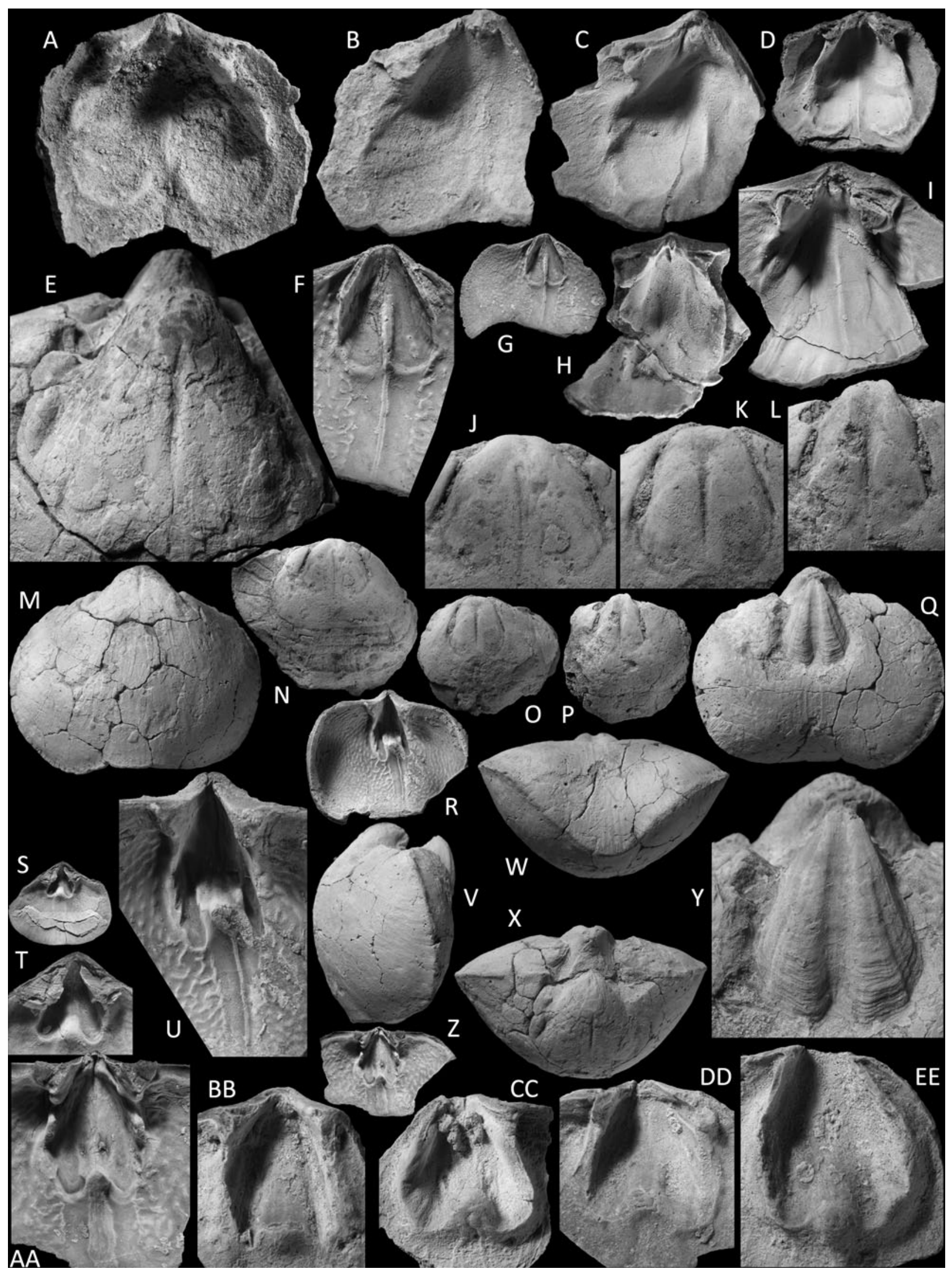


4 Fig. 4 Internal morphology of Schizophoria (Schizophoria). Entire or subentire valves $(G, M-S, V-X, Z)$, natural size; fragmentary muscle fields and enlargements of muscle fields $(A-F, H-L, T-U, Y, A A-E E)$, $\times 2.5$. A-C, E, M, $Q, V-Y, B B-E E$ Schizophoria (S.) schnuri prohibita ssp.n. $A$. Górno, Józefka quarry; Laskowa Góra beds, upper Givetian (stratotopotypic paratype). $B-C, E, M, Q, V-Y, B B-E E$ Górno, trench (approximately topotypic paratypes). $A-C$ Dorsal muscle fields ZPAL Bp 64/1/1/6 and 64/1/2/7,8. E, $M, Q, V-Y$ Internal mould ZPAL Bp $64 / 1 / 2 / 2$ in dorsal $(M)$, lateral $(V)$, anterior $(W)$, posterior $(X)$ and ventral $(Q)$ views with enlargements of the dorsal $(E)$ and ventral $(Y)$ muscle fields. $B B-E E$ Ventral muscle fields ZPAL Bp 64/1/2/3-6. $D, S-T$ Schizophoria (S.) schnuri schnuri Struve, 1965. Błonia Sierżawskie near Świętomarz, lower Givetian. $D$ Dorsal muscle field ZPAL Bp 64/2/1/1. $S-T$ Ventral interior ZPAL Bp 64/2/1/2 and enlargement of the muscle field. $I, F-G, R, U, Z-A A$ Schizophoria $(S$.) schnuri biscissa Struve, 1965. Skały, 'fundamental pit'; Skały beds, upper Eifelian. I Dorsal muscle field ZPAL Bp 64/3/5. F, G Dorsal interior and enlargement of the muscle field ZPAL Bp 64/3/6. $R$, $U$ Ventral interior and enlargement of the muscle field ZPAL Bp 64/3/ 7. $Z, A A$ Ventral interior and enlargement of the muscle field $\mathrm{ZPAL}$ Bp 64/3/8. H, J-L, N-P Schizophoria (S.) interstrialis Biernat, 1954. Grzegorzowice; Grzegorzowice Formation, upper Emsian. $H$ Dorsal muscle field ZPAL Bp IV/2/2 (paralectotype); specimen figured by Biernat (1954: text-fig. 6). $J, N ; K, O ; L, P$ Three moulds of ventral interiors ZPAL IV/2/3-5 (paralectotypes) and enlargements of muscle fields; specimens figured by Biernat (1954: text-fig. 7)

A large part of specimens from outcrop SK-3 at Skały conforms closely to the description of $S$. (S.) schnuri biscissa Struve, 1965. However, a certain number of specimens are referable rather to $S$. (S.) schnuri junkerbergiana Struve, 1965; For example, a very large shell figured by Biernat (1959, pl. 8: 1-5) has the maximal width at midlength and a very narrow deflection of the anterior commissure, both characters diagnostic for the latter subspecies. Some intermediary forms between the morphotypes corresponding to both subspecies are figured in Fig. 5. S. (S.) schnuri biscissa and S. (S.) schnuri junkerbergiana cannot therefore be interpreted as geographic variants.

It should be reminded that the available samples from the outcrop SK-3 have not been collected bed by bed; what is more, co-occurrence of Primipilaria praeprimipilaris Struve, 1992 and P. primipilaris (von Buch, 1834) evidences that several distinct levels are indeed present (Halamski 2005). The co-occurrence of the two above-mentioned morphotypes of Schizophoria in the studied material does not prove their co-occurrence in vivo (but does not disprove it either). Three different, equally tenable interpretations may therefore be proposed: either S. schnuri biscissa and S. schnuri junkerbergiana are ecologic variants that did not co-occur in vivo (and should not be distinguished taxonomically) or two extremes of a continuous variation series co-occurring in vivo (same conclusion), or else two chronosubspecies, therefore necessarily overlapping in some point of a timescale (and should be distinguished).
The latter conclusion seems to emerge from the analysis of the Eifel data (Struve 1965: fig. 4); it is, however, not testable on the available data from the single, stratigraphically imprecise (even if large) sample from the Holy Cross Mts.

The sample from the 'fundamental pit' at Skały is therefore identified as $S$. schnuri biscissa, according to the morphology of most specimens; the remaining individuals are referred to as $S$. (S.) schnuri ssp. indet., either morphotype junkerbergiana (Fig. 5A) or intermediate between the two above-mentioned ones (Fig. 5B-D).

Schizophoria (Schizophoria) schnuri schnuri Struve, 1965 (Figs. 4D, S, T; 6A-T; 8B)

\section{v. 2005 Schizophoria schnuri (Schlottheim)—Zapalski, fig. 4D \\ vp 2009 Schizophoria (Schizophoria) cf. schnuri Struve, 1965-Halamski, p. 87; text-fig. 17; pl. 14: 11, 17; 15: 11-15; non 16: 10, 14, 15, 23, 24 [ubi syn.]}

Material: about 20 articulated shells, one dorsal and one ventral valve from outcrop SW-2 sensu Halamski (2009), collection numbers ZPAL Bp 48/28 and ZPAL Bp 64/2/1; a single specimen from a well in Włochy, ZPAL Bp 64/2/2/1.

Description: Shell medium-sized (up to $32 \mathrm{~mm}$ in width), transverse, dorsibiconvex, subelliptic in outline. Maximal width at about midlength of the shell. Posterior margin straight, attaining up to $3 / 4$ of the shell width; anterior commissure uniplicate, linguiform extension moderately wide (1/3-1/2 of the shell width), low to moderately high, rounded. Dorsal valve convex, elliptic to parabolic in anterior view, the umbonal region not seldom extending more posteriorly than the ventral umbo, dorsal beak rather thick, markedly incurved. Dorsal interarea apsacline to orthocline. Ventral valve moderately convex in the umbonal region, with an incipient sulcus extending anteriorly from midlength. Ventral interarea apsacline.

Ornamentation of moderately coarse radial costellae, 2-3 per $\mathrm{mm}$, either of approximately the same thickness (aequicostellate) or some of them finer than the other (parvicostellate), separated by somewhat wider furrows. Costellae arising by bifurcation and intercalation. Growth lines very fine, rarely preserved.

Ventral interior: teeth moderately strong, muscle area wide.

Dorsal interior: the single juvenile dorsal valve has a relatively small and narrow muscle area; the scars are separated by a broad median elevation with a faint and narrow median ridge. 


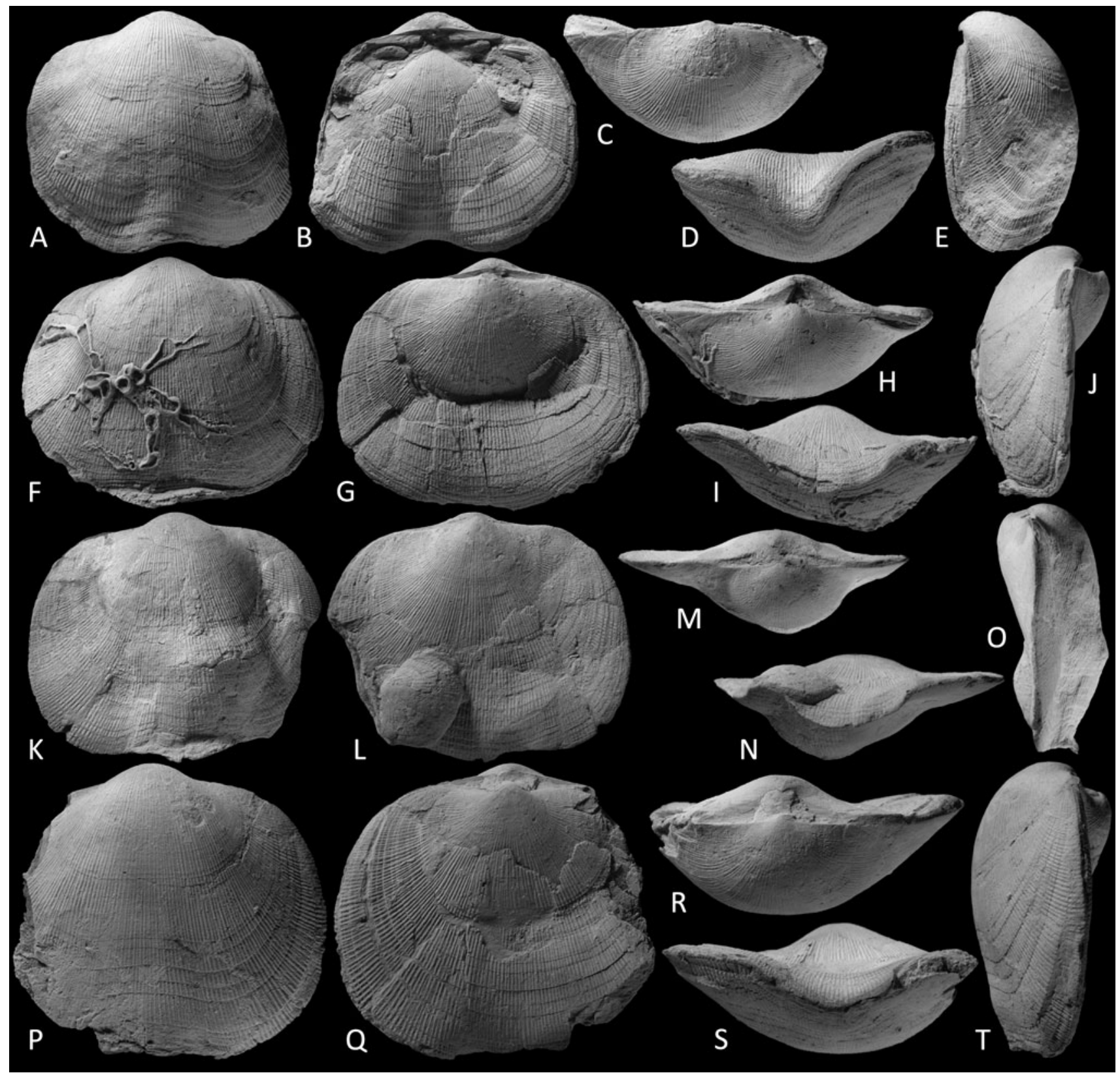

Fig. 5 Schizophoria (S.) schnuri Struve, 1965 (ssp. indet.). Individuals of intermediate morphology between $S$. (S.) schnuri biscissa Struve, 1965 and S. (S.) schnuri junkerbergiana Struve, 1965 in dorsal, ventral, posterior, anterior and lateral views. All specimens from the 'fundamental pit' in Skały (Skały beds, upper Eifelian) and

Punctae medium-sized, ca. (15-)21-27 $\mu \mathrm{m}$ in diameter, distributed moderately densely, ca. 205-270 per $\mathrm{mm}^{2}$.

Remarks: The sample from Błonia Sierżawskie was previously described by Zapalski (2005) and Halamski (2009) on the basis of limited material as Schizophoria schnuri and Schizophoria (S.) cf. schnuri, respectively. A larger sample allowed a precise identification. The shown natural size. A-E Articulated shell (junkerbergiana-morphotype) ZPAL Bp 64/3/9. F-J Articulated shell (intermediate morphotype) ZPAL Bp 64/3/10. $K-O$ Articulated shell (intermediate morphotype) ZPAL Bp 64/3/11. $P-T$ Articulated shell (intermediate morphotype) ZPAL Bp 64/3/12

differences with S. schnuri prohibita ssp.n. are discussed below.

Schizophoria (Schizophoria) schnuri prohibita ssp.n. (Figs. 4A-C, E, M, Q, V-Y, BB-EE; 7A-II; 8C, E)

vp 2009 Schizophoria (Schizophoria) cf. schnuri Struve, 1965-Halamski, p. 87; text-fig. 17; pl. 16: 10, $14,15,23,24$; non $14: 11,17 ; 15: 11-15$ 


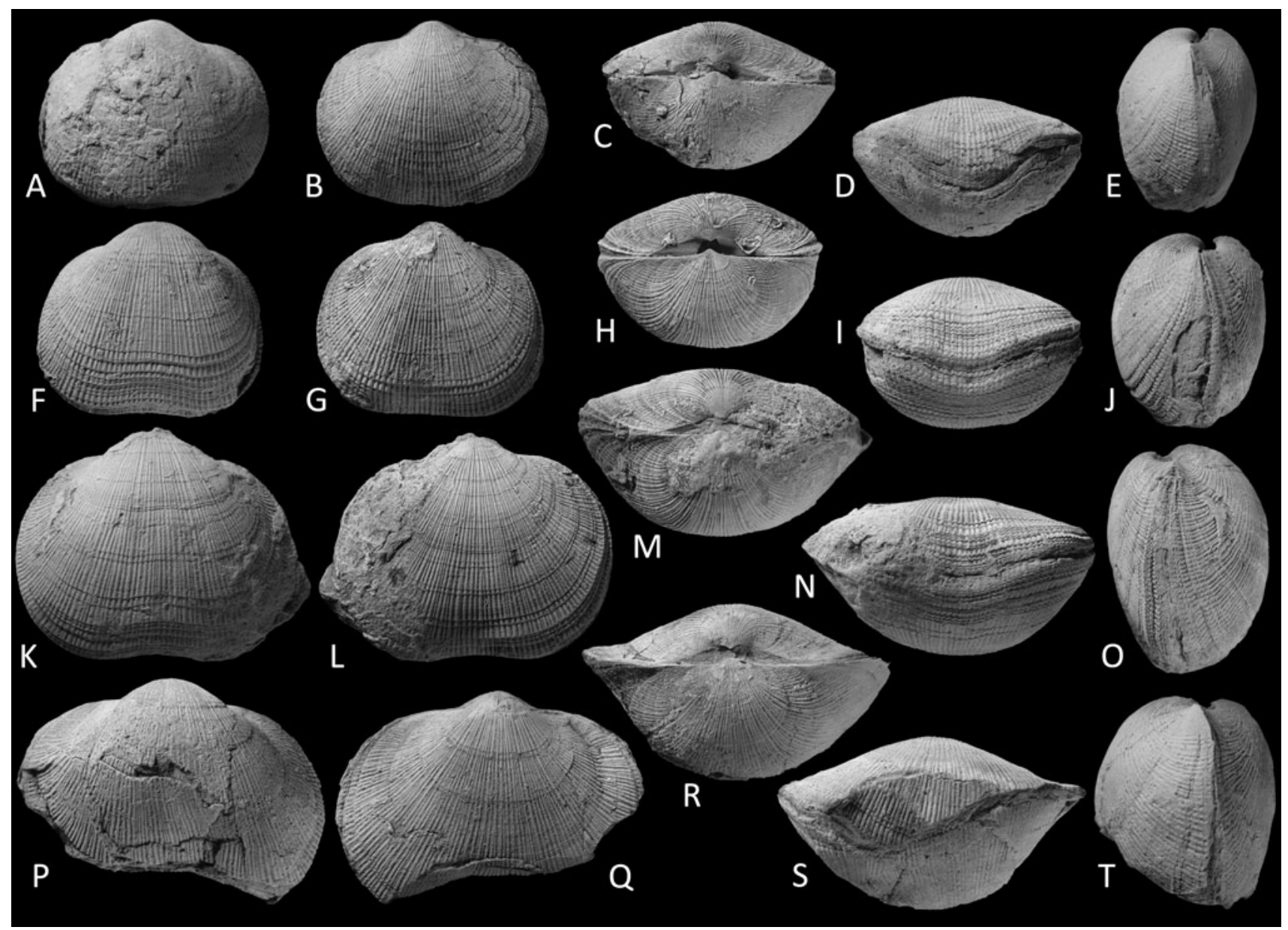

Fig. 6 External morphology of Schizophoria (Schizophoria), continued. Articulated shells in dorsal, ventral, posterior, anterior and lateral views. All specimens shown $\times 1.5$. A-T Schizophoria $(S$.) schnuri schnuri Struve, 1965. Błonia Sierżawskie near Swiętomarz; Skały

Diagnosis: Schizophoria schnuri rounded-subrectangular in outline, with wide tongue and dorsal muscle field wider than long.

Locus typicus: Józefka quarry (eastern wall), Górno, Holy Cross Mts.

Stratum typicum: Laskowa Góra beds, upper Givetian.

Derivatio nominis: prohibitus, in Latin 'forbidden'-in allusion to the difficult access to the type outcrop.

Type material: Holotype, articulated shell ZPAL Bp 64/1/1/1 (Fig. 7Z-DD; stratotopotypic paratypes, four articulated shells from the type outcrop ZPAL Bp 64/1/1/ 2-5 (Fig. 7F-T, EE-II); approximately stratotopotypic paratype ZPAL Bp 64/1/2/1 from the outcrop in Górno (Fig. 5U-Y); non-topotypic paratype from Laskowa Góra ZPAL Bp 64/1/3/1 (Fig. 7A-E); one complete internal mould (approximately topotypic paratype) ZPAL Bp 64/1/ 2/2 (Fig. 4E, M, Q, V-Y); four ventral muscle fields beds, lower Givetian. A-E Specimen ZPAL Bp 64/2/1/3. F-J Specimen ZPAL Bp 64/2/1/4. $K-O$ Specimen ZPAL Bp 64/2/1/5. $P-T$ Specimen ZPAL Bp 64/2/1/6

(approximately topotypic paratypes) ZPAL Bp 64/1/2/3-6 (Fig. 4BB-EE); three dorsal muscle fields, one stratotopotypic paratype ZPAL Bp 64/1/1/6 (Fig. 4A) and two approximately topotypic paratypes ZPAL 64/1/2/7,8 (Fig. 4B, C); several more fragmentarily preserved stratotopotypic paratypes, collection ZPAL Bp 64/1/1; a single nontopotypic paratype from Nieczulice, ZPAL Bp 48/28/3/1.

Description: Shell rather large to large (up to $41.2 \mathrm{~mm}$ in width), transverse, dorsibiconvex, subrectangular in outline with markedly rounded postero-lateral and antero-lateral extremities. Maximal width at about midlength of the shell. Posterior margin straight, attaining up to $3 / 4$ of the shell width; anterior commissure usually slightly indented, uniplicate, linguiform extension moderately wide $(1 / 3-1 / 2$ of the shell width), seldom more, low to moderately high, rounded. Dorsal valve strongly convex, semi-elliptic to parabolic in anterior view, the umbonal region not seldom extending more posteriorly than the ventral umbo, dorsal 


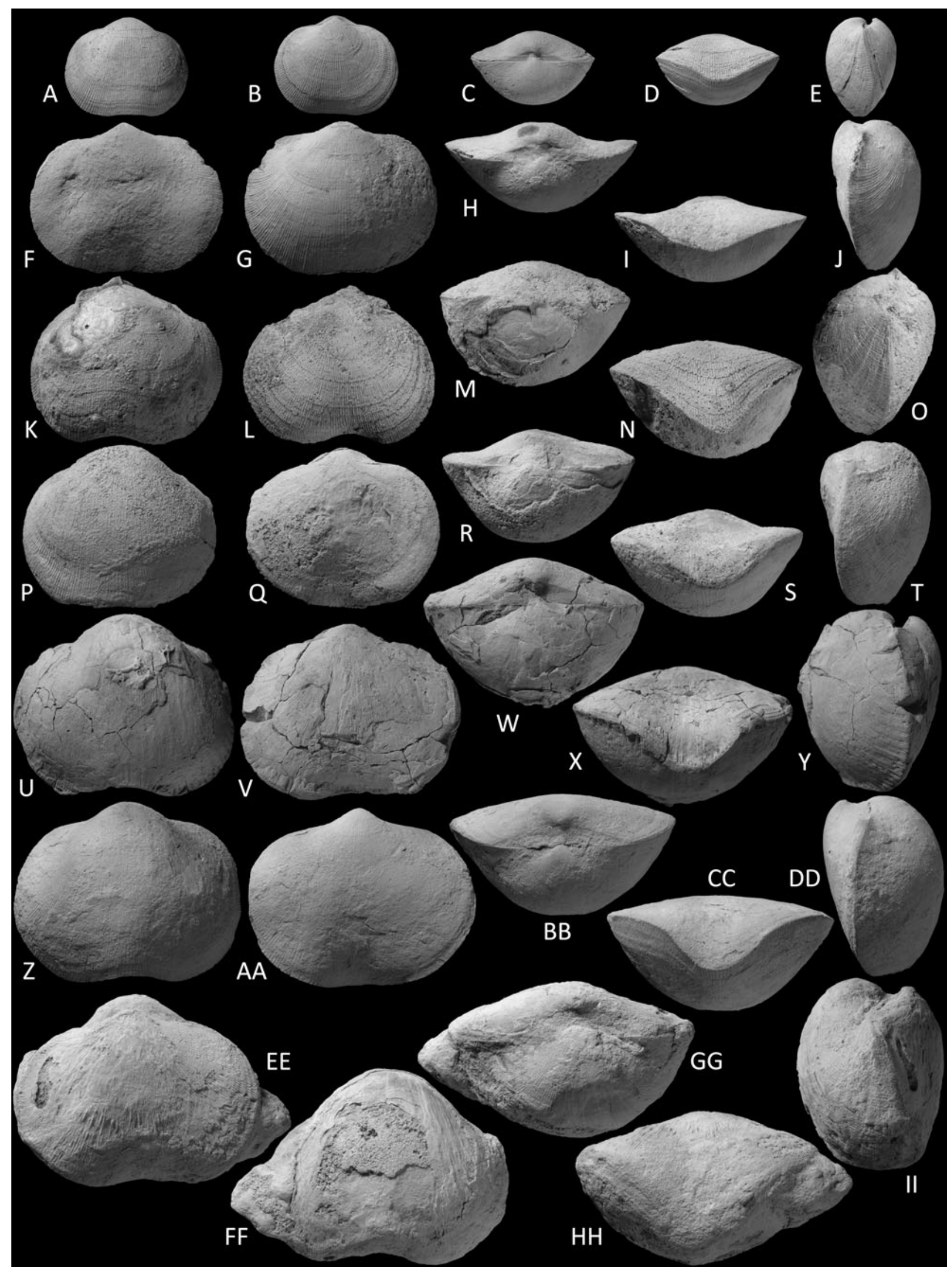


Fig. 7 External morphology of Schizophoria (Schizophoria), continued. Articulated shells in dorsal, ventral, posterior, anterior and lateral views. All specimens shown natural size. A-Y Schizophoria (S.) schnuri prohibita ssp.n. A-E Non-topotypic paratype from Laskowa Góra quarry, Laskowa Góra beds, upper Givetian. F-T, EE-II Topotypic paratypes from Górno, Józefka quarry; Laskowa Góra beds, upper Givetian. $U-Y$ Approximately topotypic paratypes from Górno, trench. A-E Paratype ZPAL Bp 64/1/3/1. F-J Paratype ZPAL Bp 64/1/1/2. K-O Paratype ZPAL Bp 64/1/1/3. $P-T$ Paratype ZPAL Bp 64/1/1/4. $U-Y$ Paratype ZPAL Bp 64/1/2/1. Z-DD Holotype ZPAL Bp 64/1/1/1. EE-II Paratype ZPAL Bp 64/1/1/5

beak rather thick, markedly incurved. Dorsal interarea apsacline to orthocline. Ventral valve moderately convex in the umbonal region, with a very broad, shallow sulcus extending anteriorly from midlength. Ventral interarea apsacline.

Ornamentation of moderately coarse radial costellae, 2-3 per $\mathrm{mm}$, most often of approximately the same thicknesses, seldom parvicostellate, separated by somewhat wider furrows. Costellae arising by bifurcation and intercalation, the former apparently more frequent. Growth lines not observed.

Ventral interior: teeth relatively high, narrow, divergent at $75^{\circ}$. The muscle field is about $15 \mathrm{~mm}$ wide and $14 \mathrm{~mm}$ long, bisected by an indentation ca. $3 \mathrm{~mm}$ long. A low and rather thin median septum prolongs the indentation posteriorly to about half the length of the muscle field.

Dorsal interior: unknown.

Punctae medium-sized, ca. (13-20)-27 $\mu \mathrm{m}$ in diameter, distributed moderately densely, ca. $185-205$ per $\mathrm{mm}^{2}$.

Remarks: The above-described middle to late Givetian form is quite similar to the early Givetian Schizophoria $(S$.) schnuri schnuri (see above). The mean size of the shell in the Górno sample is smaller than that of $S$. (S.) schnuri schnuri from Świętomarz, but this is due to ecologic factors as $S$. (S.) schnuri schnuri from the Eifel is up to $38.9 \mathrm{~mm}$ wide. The shape of shells from both samples is quite the same. On the contrary, dorsal muscle fields of specimens from Górno are wider than long whereas those from the Świętomarz sample are longer than wide (compare Figs. 3B and 4A herein and pl. 14: 1, 2, 12 in Halamski 2009; corresponding data for the Eifel are unfortunately not available). Given the stratigraphic gap separating the two samples, the Górno material is described here as a new subspecies in the Schizophoria (S.) schnuri lineage.

\section{Schizophoria (Schizophoria) sp.n. (Fig. 2A-J)}
? 1970
Schizophoria striatula-Dürkoop, p. 181-183, pl. 14: 7-10
v. 1993b Schizophoria aff. mcfarlanei (Meek, 1868)- Racki, p. 300, fig. 1H-I

Material: two fragmentarily preserved shells and one fragment from the eastern hill at Trzemoszna, Givetian; GIUS 4-219.

Description: Shell small (up to $22 \mathrm{~mm}$ in width), transverse (width to length ratio 1.18-1.36), ventribiconvex, often teardrop-shaped in outline with approximately straight anterior margin, sometimes more transverse. Maximal width usually at about midlength (anterior or posterior to it, according to the individual). Hinge line attaining ca. 0.6 of the total width of the shell. Anterior commissure broadly and shallowly uniplicate, sulcus very wide (0.8-0.9 of the shell width), relatively shallow. Dorsal valve relatively low, broadly triangular in anterior view. Ventral valve very high, parabolic in anterior view; umbo thick, incurved, extending over the hinge line; sulcus very shallow, apparent only in the proximity of the anterior margin. Ventral interarea anacline, dorsal area very high, nearly flat, slightly hypercline.

Ornamentation of fine, rounded, tubular radial costellae, 3-4 per $\mathrm{mm}$, separated by narrower furrows.

Dorsal interior: trace of an elongate (about half of the shell length, length to width ratio 1.5) and deeply medially indented (over $1 / 3$ of its length, Fig. 2F) muscle area. Interior otherwise unknown.

Shell structure: not studied.

Remarks: The Givetian to Frasnian Schizophoria (S.) macfarlanei (Meek, 1868) has a very characteristic strongly dorsibiconvex shell (Meek 1868: 88, pl. 12, 1; Shimer and Shrock 1944: pl. 140: 1-3; Stigall Rode 2005: 151, fig. 5.5-5.7). Its conspecificity with the described material may be excluded.

Schizophoria striatula sensu Dürkoop, 1970 from the Middle Devonian of Rukh (Afghanistan) resembles Schizophoria (S.) sp.n. described here in external form of the shell and the narrow, deeply indented dorsal muscle field (Dürkoop 1970: pl. 14, 7-10) but the position of the dorsal interarea is different (hypercline in the described material and anacline in that from Afghanistan).

Schizophoria macfarlanii var. galeatiformis Grabau, 1931 from the 'late Middle Devonian of South China' (Grabau 1931-33: 70-71, pl. 7: 8, 9, 14) is rather similar to Schizophoria $(S$.$) sp.n. in lateral profile; the differences$ include the position of the area and the shape of the valves (longer than wide).

The described material represents probably a new species which is not named due to lack of sufficient material.

Schizophoria (Schizophoria) parvaepunctata von Kelus 1939 (Fig. 3A-O) 

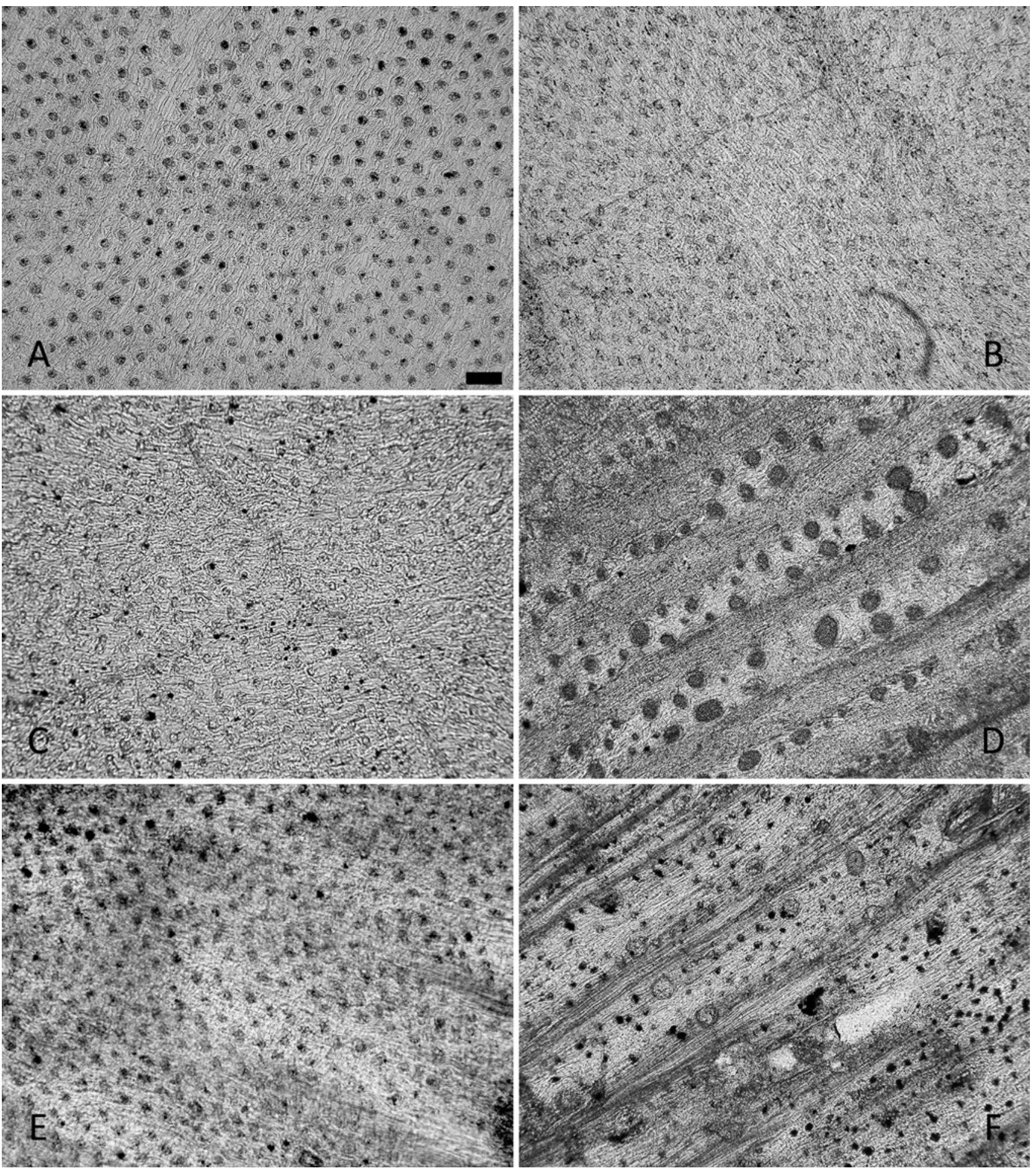

Fig. 8 Tangential sections of Schizophoria shells. Scale bar $100 \mu \mathrm{m}$. a Schizophoria (S.) schnuri biscissa Struve, 1965. Skały, 'fundamental pit'; Skały beds, upper Eifelian. Thin section ZPAL 64/3/S1. b Schizophoria (S.) schnuri schnuri Struve, 1965. Błonia Sierżawskie near Świętomarz; Skały beds, lower Givetian. Thin section ZPAL 64/2/S1. c Schizophoria (S.) schnuri prohibita ssp.n. Górno, Józefka

quarry; Laskowa Góra beds, upper Givetian. Thin section ZPAL 64/1/ S1. d, f Schizophoria (Pachyschizophoria) cf. vulvaria (von Schlotheim, 1820). Cabo la Vela section, Cantabrian Mts., Spain; La Ladrona Formation, upper Emsian. Thin sections ZPAL 64/A/S1,2. e Schizophoria (S.) interstrialis Biernat, 1954. Grzegorzowice; Grzegorzowice Formation, upper Emsian. Thin section ZPAL 64/4/S1 
* 1939 Schizophoria resupinata var. parvaepunctataKelus, p. 33-36; text-fig. 25e; pl. 2: 18-21

v. 1950 Schizophoria striatula var. parvaepunctata Kelus-Samsonowicz, p. 410, 412, 413, 418, 419

Type material: The original specimens of von Kelus (1939) were destroyed during World War II. The specimen MWG 02619/1, an (approximate) topotype from J. Samsonowicz's collection (illustrated herein in Fig. $3 \mathrm{~K}-\mathrm{O}$ ), is selected herein as the neotype.

Material: five articulated shells MWG 02619/1-5.

Description: Shell medium-sized (up to $29.6 \mathrm{~mm}$ in width), slightly to distinctly transverse, strongly dorsibiconvex, elliptic in outline. Maximal width approximately at midlength, maximal thickness posteriorly. Posterior margin straight, attaining ca. $0.6-0.65$ of the shell width; anterior commissure uniplicate, tongue relatively narrow to relatively wide, high, subtriangular. Dorsal valve strongly convex, semi-elliptic to parabolic in anterior view, the umbonal region often extending more posteriorly than the ventral umbo, dorsal beak rather fine, markedly incurved. Dorsal interarea apsacline to orthocline. Ventral valve moderately convex in the umbonal region, with a very broad, shallow to occasionally deeper sulcus extending anteriorly from midlength. Ventral interarea apsacline. Delthyrium and notothyrium rather narrow, not exceeding $1 / 5$ of the width of the interarea.

Ornamentation of fine, rounded, tubular radial costellae, 3-5 per $\mathrm{mm}$, separated by somewhat wider furrows. Costellae arising by both bifurcation and intercalation. Growth lines rather strong, $2-4$ per $5 \mathrm{~mm}$ in posterior and central region, much denser in the anterior region of the adults.

Punctae very small, ca. 5-9 $\mu \mathrm{m}$ in diameter, distributed moderately densely, ca. 190 per $\mathrm{mm}^{2}$.

\section{Distribution of punctae ${ }^{2}$ as a systematic criterion}

Punctae or pores are shell perforations found in several unrelated groups of articulates: enteletaceans among orthides, retziidines among athyridides, spiriferinides,

\footnotetext{
${ }^{2}$ It may be noted that the name of this anatomic structure is taken from Latin puncta 'the action of pricking' (first declension, feminine), much rarer than usual punctum 'the action or the mark of pricking' (second declension, neuter; Gesner 1749: 1178; Plezia 1959: 389). Both forms have been used by palaeontologists. The former one, namely puncta, plural punctae, although less correct from a strictly linguistic point of view, has been recommended by the editors of the Treatise (Williams and Brunton 1997: 436) followed by a majority of modern authors; it is also used in the present text.
}

terebratulides and thecideides, as well as in a few genera of rhynchonellides (Rudwick 1970; Williams 1997). The spatial pattern of their distribution has been shown to be both of some systematic value (Foster 1974: fig. 25, density; fig. 26, pore size) and influenced by external factors (Ackerly et al. 1993).

In particular, concerning orthides, Leidhold (1925) suggested that punctae distribution might be a valuable systematic criterion (among others, in Schizophoria). Despite several reservations, Kozłowski (1929), Schuchert and Cooper (1932) and Cloud (1942) concluded that at least in some cases this was actually the case. On the contrary, in a part of a study of Devonian fauna of Volhynia dealing with representatives of the genus Schizophoria, von Kelus (1939) arrived to an opposite conclusion on account of high within-individual and (presumed) intraspecific variation. This result must, however, be considered unsound, as his 'Schizophoria striatula' included at least three different taxa (S. schnuri, S. parvaepunctata and an unidentified Frasnian species from Boulonnais). Biernat (1959), despite detailed studies of a very large material (over 10,000 specimens), was unable to give any definite conclusions, stating that "problems of the systematic significance of punctae still require further work" (Biernat 1959: 8). It has therefore seemed interesting to reassess the value of the above-mentioned criterion in a sample consisting of all the representatives of a genus (namely Schizophoria) within a given period and including, in particular, the intraspecific variation within more narrowly defined taxa.

Tangential sections were made from shells of Schizophoria (S.) schnuri biscissa, S. (S.) schnuri schnuri and $S$. (S.) schnuri prohibita (see descriptions above). The original sections of $S$. (S.) interstrialis by Biernat were used too. No material of $S$. (S.) parvaepunctata or Schizophoria (S.) sp.n. was available for sectioning, nonetheless corresponding values for the former species could have been estimated from the description and figure (25e) in von Kelus (1939). For comparison, two shells of Schizophoria (Pachyschizophoria) cf. vulvaria from the upper Emsian of the Cabo la Vela section (La Ladrona Formation, Cantabrian Mts., Spain) have also been sectioned. Sections were examined under Zeiss biologic light microscope: puncta diameter was measured using a $40 \times$ objective, whereas punctae density was counted under a $16 \times$ objective on a surface of $0.37 \mathrm{~mm}^{2}$ on each section. Two counts were made per individual. The results are presented in the systematic descriptions above and summarised in Table 2.

The results may be systematised as follows: three groups of taxa can be distinguished according to the punctae characteristics. Schizophoria (Pachyschizophoria) cf. vulvaria is characterised by relatively large and sparsely 
Table 2 Numeric characteristics of punctae distribution in selected species of Schizophoria

\begin{tabular}{|c|c|c|c|c|c|c|c|}
\hline \multirow[t]{2}{*}{ Subgenus } & \multirow[t]{2}{*}{ Group } & \multirow[t]{2}{*}{ Species } & \multirow[t]{2}{*}{ Individual } & \multirow{2}{*}{$\begin{array}{l}\text { Puncta } \\
\text { diameter } \\
(\text { in } \mu \mathrm{m})\end{array}$} & \multirow{2}{*}{$\begin{array}{l}\text { Punctae } \\
\text { density } \\
\left(\text { per } \mathrm{mm}^{2}\right)\end{array}$} & \multicolumn{2}{|c|}{ Variation within taxa } \\
\hline & & & & & & $\begin{array}{l}\text { Puncta } \\
\text { diameter }\end{array}$ & $\begin{array}{l}\text { Punctae } \\
\text { density }\end{array}$ \\
\hline $\begin{array}{l}\text { Schizophoria } \\
\quad \text { (Pachy- } \\
\text { schizophoria) }\end{array}$ & - & $\begin{array}{l}\text { Schizophoria }(P .) \text { cf. vulvaria } \\
\text { Cantabrian Mts., upper } \\
\text { Emsian }\end{array}$ & A & $15-45(-90)$ & 120 & $15-45(-90)$ & 120 \\
\hline \multirow[t]{5}{*}{$\begin{array}{l}\text { Schizophoria } \\
\quad(\text { Schizophoria })\end{array}$} & S. (S.) praecursor & $\begin{array}{l}\text { Schizophoria }(S .) \text { interstrialis } \\
\text { Grzegorzowice, upper Emsian }\end{array}$ & $\mathrm{B}$ & $20-30$ & 170 & $20-30$ & 170 \\
\hline & \multirow[t]{3}{*}{ S. (S.) schnuri } & $\begin{array}{l}\text { Schizophoria }(\text { S.) schnuri } \\
\quad \text { biscissa } \\
\text { Skały, upper Eifelian }\end{array}$ & $\begin{array}{l}\mathrm{C} \\
\mathrm{D} \\
\mathrm{E}\end{array}$ & $\begin{array}{l}13-18(-23) \\
15-24 \\
(13-) 15-27\end{array}$ & $\begin{array}{l}215-240 \\
365-400 \\
260-275\end{array}$ & $13-27$ & $215-400$ \\
\hline & & $\begin{array}{l}\text { Schizophoria }(\text { S.) schnuri } \\
\text { schnuri } \\
\text { Świętomarz, lower Givetian }\end{array}$ & $\mathrm{F}$ & (15-) 21-27 & $205-270$ & $15-27$ & $205-270$ \\
\hline & & $\begin{array}{l}\text { Schizophoria }(S .) \text { schnuri } \\
\text { prohibita } \\
\text { Górno, upper Givetian }\end{array}$ & G & $13-20(-27)$ & $185-205$ & $13-27$ & $185-205$ \\
\hline & - & $\begin{array}{l}\text { Schizophoria }(S .) \\
\text { parvaepunctata } \\
\text { Pełcza, Givetian }\end{array}$ & $\mathrm{H}$ & $5-9$ & 190 & $5-9$ & 190 \\
\hline
\end{tabular}

Values have been rounded. See text for further explanations

distributed punctae (diameter up to $45 \mu \mathrm{m}$ in the central region of the valve, up to $90 \mu \mathrm{m}$ in marginal region). Schizophoria $(S$.) parvaepunctata is characterised by very small (less than $10 \mu \mathrm{m}$ in diameter) and moderately densely distributed (190 per $\mathrm{mm}^{2}$ ) punctae. Schizophoria $(S$.) interstrialis and all the subspecific variants of Schizophoria (S.) schnuri have medium-sized punctae $(15-30 \mu \mathrm{m}$ in diameter) of moderately dense distribution (185-400 per $\mathrm{mm}^{2}$ ). The intraspecific variability of these characters is quite important.

The punctae distribution in Schizophoria (Pachyschizophoria) cf. vulvaria is certainly the most unusual among the patterns described here, as it is quite different from both the above-mentioned fossil material and recent taxa. In effect, the distribution of the punctae was studied in some detail in recent terebratulides, and it has been shown that in all studied species the pattern of the spatial positioning of the punctae was similar, consisting of more or less uniformly sized punctae disposed without significant changes in density (Foster 1974: fig. 3). A similar pattern may be observed in numerous published illustrations of both fossil and Recent terebratulides (a few examples may be quoted: Recent Gryphus vitreus, Ruggiero 1983: pl. 1, fig. 3; Recent Argyrotheca cuneata, Ruggiero 1987: pl. 2, figs. 1-7; Recent Megathiris detruncata, Benigni 1987: fig. 6; Ruggiero 1987: pl. 5, figs. 1-3; Recent Phaneropora galatheae, Bitner 2008: fig. 15; Eocene Magella australis, Bitner 1996: pl. 23, fig. 3 and unpublished data; several Cretaceous representatives of genera Sellithyris, Rectithyris, Concinnithyris, and others, Gaspard 1970). Thecideids seem to have a slightly less regular yet broadly similar pattern (Jurassic Rioultina wapiennensis, Krawczyński 2008: pl. 2, figs. 4, 6; Recent Thecidellina minuta, Bitner 2010: fig. 5). On the contrary, Schizophoria (P.) cf. vulvaria is characterised by an unusual pattern consisting in punctae of very different sizes (the largest ones being up to six times wider than the smallest) intermingled among one other (Fig. 8D). The only analogue found for such a distribution is that found in Middle Devonian Levenea depressa Wang, 1956 from Kwangsi (now Guangxi), South China (Wang, 1956: pl. 3, fig. D6; the image is, unfortunately, poorly legible). This shows that shell structure in brachiopods is still relatively poorly studied. Lack of data on punctae size and density has recently been stressed also by Pérez-Huerta et al. (2009).

\section{Conclusions}

1. The nominative subgenus of the genus Schizophoria in the Lower and Middle Devonian of Poland (Łysogóry and Kielce Regions, Holy Cross Mts.) and of western Ukraine (Volhynia) is represented by the following taxa:

(a) Schizophoria (Schizophoria) interstrialis in the upper Emsian of Grzegorzowice (Łysogóry Region); 
(b) Schizophoria (S.) schnuri biscissa in the upper Eifelian of Skały (Łysogóry Region); some morphotypes from the same outcrop are referable to $S$. (S.) schnuri junkerbergiana, wherefore the separation of these subspecies may be maintained only if they are considered as chronosubspecies (unverifiable on the studied material) but not as geographic variants (hypothesis falsified by the studied material);

(c) Schizophoria (S.) schnuri schnuri in the lower Givetian of Błonia Sierżawskie near Świętomarz and of Włochy (Łysogóry Region);

(d) Schizophoria (S.) schnuri prohibita ssp.n. in the middle to upper Givetian of Górno (Kielce Region) and of Nieczulice (Łysogóry Region);

(e) Schizophoria (S.) sp.n. (unnamed for lack of sufficient material) in the upper Givetian of Trzemoszna (Kielce Region);

(f) Schizophoria (S.) parvaepunctata in the middle Givetian of Povcha (Volhynia).

2. Within the genus Schizophoria, punctae diameter and density may serve as a systematic criterion between groups of species but not within a lineage of closely related taxa. S. (Pachyschizophoria) and S. (S.) parvaepunctata differ between one another and from all other investigated species of $S$. (Schizophoria); the latter are indistinguishable on the sole basis of punctae characteristics.

3. The punctae distribution pattern in Schizophoria (Pachyschizophoria) cf. vulvaria consists of intermingled punctae of very different diameters. Such a condition is apparently very rare among brachiopods.

Acknowledgments The author was introduced to the Górno section by Prof. Grzegorz Racki (Silesian University, Sosnowiec and Institute of Paleobiology, Warsaw), who also supplied the material of Schizophoria (S.) sp.n. and additional specimens of S. (S.) schnuri prohibita. The material of Schizophoria $(P$.) cf. vulvaria was kindly provided by Dr. Ulrich Jansen (Senckenberg, Frankfurt am Main). The Volhynia material was localised and loaned through the courtesy of Mariusz Niechwedowicz (Museum of the Faculty of Geology, Warsaw University). One specimen of $S$. (S.) interstrialis was donated by Łukasz Rakowicz (formerly Institute of Paleobiology). Photographs are by Marian Dziewiński, and sections were made by Zbigniew Strąk (both Institute of Paleobiology). Prof. Andrzej Baliński (Institute of Paleobiology, Warsaw) gave field help and discussed the text. Some improvements were suggested by Dr. Mikołaj K. Zapalski (Warsaw University) and Piotr Lipiński (National Medicines Institute, Warsaw). The manuscript has been reviewed by Dr. Ulrich Jansen and Prof. Denise Brice (Faculté Libre des Sciences, Lille). All the abovementioned persons are gratefully acknowledged.

Open Access This article is distributed under the terms of the Creative Commons Attribution License which permits any use, distribution, and reproduction in any medium, provided the original author(s) and the source are credited.

\section{References}

Ackerly, S.C., J.L. Cisne, L.B. Railsback, and T.F. Anderson. 1993. Punctal density in the Ordovician orthide brachiopod Paucicrura rogata: Anatomical and paleoenvironmental variation. Lethaia 26: $17-24$.

Anderson, M.M., A.J. Boucot, and J.G. Johnson. 1969. Eifelian Brachiopods from Padaupkin, Northern Shan States, Burma. Bulletin of the British Museum (Natural History), Geology 18(4): 105-163. pls $1-10$.

Baliński, A. 1995a. Brachiopods and conodont biostratigraphy of the Famennian from the Dębnik Anticline, southern Poland. Palaeontologia Polonica 54: 1-88. pls 1-22.

Baliński, A. 1995b. Devonian athyridoid brachiopods with double spiralia. Acta Palaeontologica Polonica 40: 129-148.

Baliński, A. 2002. Frasnian-Famennian brachiopod extinction and recovery in southern Poland. Acta Palaeontologica Polonica 47(2): 289-305.

Baliński, A. 2006. Brachiopods and their response to the EarlyMiddle Frasnian biogeochemical perturbations on the South Polish carbonate shelf. Acta Palaeontologica Polonica 51(4): 647-678.

Baranov, V.V. 2008. Orthid brachiopods from the lower and middle Devonian of Northeastern Russia. Paleotological Journal 42(4): 363-372.

Barrande, J. 1879. Systême silurien du Centre de la Bohême. Ière partie : Recherches paléontologiques. Vol. 5 : Classe des Mollusques, Ordre des Brachiopodes. 226 p., 153 pls. Prague and Paris.

Benigni, C. 1987. Shell microstructure of Mediterranean terebratulid from Pliocene to recent and its diagnostic significance. Bolletino del Museo regionale di Scienze naturali, Torino 5(1): 1-26.

Biernat, G. 1954. Brachiopods from the Couvinian of Grzegorzowice. Acta Geologica Polonica 4(4): 485-533. pls I-VI.

Biernat, G. 1959. Middle Devonian Orthoidea of the Holy Cross Mountains and their ontogeny. Palaeontologia Polonica 10: 1-78. pls I-XII.

Bitner, M.A. 1996. Brachiopods from the Eocene La Meseta Formation of the Seymour Island, Antarctic Peninsula. Palaeontologia Polonica 55: 65-100. pls 18-26.

Bitner, M.A. 2008. New data on the recent brachiopods from the Fiji and Wallis and Futuna Islands, South-West Pacific. Zoosystema 30: 419-461.

Bitner, M.A. 2010. Biodiversity of shallow-water brachiopods from New Caledonia, SW Pacific, with description of a new species. Scientia Marina 74(4): 643-657.

von Buch, L.C. 1834. Über Terebrateln. Abhandlungen der königlichen Akademie der Wissenschaften zu Berlin 1834: 21-144.

Cloud, P.E., Jr. 1942. Terebratuloid Brachiopoda of the Silurian and Devonian. Geological Society of America, Special Paper 38: i-xi, 1-182, pls 1-26.

Dames, W.B. 1868. Ueber die in der Umgebung Freiburgs in NiederSchlesien auftretenden devonischen Ablagerungen. Zeitschrift der deutschen geologischen Gesellschaft 20: 469-508.

Drygant, D.M. 2010. Devonian Conodonts from south-west margin of the East European Platform (Volyn'-Podolian, Ukraine), 156, 23 pls. Kyiv: Akademperiodyka.

Duméril, A.-M.C. 1805. Zoologie analytique, ou méthode naturelle de classification des animaux, rendue plus facile à l'aide de tableaux synoptiques, 344. Paris: Allais. ['1806'; see Gregory 2010 about the date of publication].

Dupret, V., and A. Blieck. 2009. The Lochkovian-Pragian boundary in Podolia (Lower Devonian, Ukraine) based upon placoderm vertebrates. Comptes Rendus: Geoscience 341(1): 63-70. 
Dürkoop, A. 1970. Brachiopoden aus dem Silur, Devon und Karbon in Afghanistan (mit einer Stratigraphie des Paläozoikum der Dascht-E-Nawar/Ost von Rukh). Palaeontographica 134(4/6): 153-225, pls 14-19.

Foster, M.W. 1974. Recent Antarctic and subantarctic brachiopods. Antarctic Research Series 21: 1-189.

von Gaertner, H.-R., and H.W. Walther (eds.). 1971. International geological map of Europe and the Mediterranean Region. International Geological Congress-Commission for the Geological Map of the World. Hannover: Bundesanstalt für Bodenforschung and UNESCO.

García-Alcalde, J. 2001. Paleobiogeographical relationships between North Gondwana South Baltica: The Ivanothyris havliceki fauna Cantabrian Zone, latest Emsian). Journal of the Czech Geological Society 46(3/4): 121-130.

Gaspard, D. 1970. Structure et microstructure du test des Terebratules du Crétacé supérieur, 62, XXI pls. Université de Paris, Faculté des Sciences d'Orsay.

Gesner, I.M. 1749. Novus linguae et eruditionis Romanae Thesaurus post Ro. Stephani et aliorum nuper etiam in Anglia eruditissimorum hominum curas digestus, locupletatus, emendatus; et Georgio II, defensori Fidei et pacatori orbis, bibliothecam Academiae suae Georgiae Augustae, quae Gottingae est, invisenti, devoti animi pietate oblatus a.D. XXX.IVL.CIC.ICCC.XXXXVIII; a Io. Mathia Gesnero. Tomus III: L-P, 1196. Lipsiae: impensis Casp. Fritschii viduae et Bernh. Christ. Breitkopfii.

Grabau, A.W. 1931-33. Devonian Brachiopoda of China. I: Devonian Brachiopoda from Yunnan and other Districts in South China. Palaeontologia Sinica B 3(3):1-545, pls I-LIV [text 1931, plates 1933].

Gregory, S.M.S. 2010. The two 'editions' of Duméril's Zoologie analytique, and the potential confusion caused by Froriep's translation Analytische Zoologie. Zoological Bibliography 1(1): $6-8$.

Gunia, T. 1968. On the fauna, stratigraphy and conditions of sedimentation of the upper Devonian in the Świebodzice depression (Middle Sudetes). Geologia Sudetica 4: 115-220.

Halamski, A.T. 2005. Annotations to the Devonian Correlation Table, R220dm05: Poland; Holy Cross Mts; Łysogóry Region. Senckenbergiana Lethaea 85(1): 185-187.

Halamski, A.T. 2009. Middle Devonian Brachiopods from the northern Part of the Holy Cross Mountains, Poland in relation to selected coeval faunas. Part I: Introduction, Lingulida, Craniida, Strophomenida, Productida, Orthotetida, Protorthida, Orthida. Palaeontographica, Abteilung A 287(1/3): 41-98, pls 1-16.

Halamski, A.T., and G. Racki. 2005. Supplements 2005. In: Devonian Correlation Table, ed. Weddige, K. With 24 Table-columns. Senckenbergiana lethaea 85(1): 191-200, Frankfurt am Main.

Halamski, A.T., and T. Segit. 2006. A transitional stringocephalid from the Holy Cross Mountains, Poland, and its evolutionary and stratigraphic significance. Acta Geologica Polonica 56(2): 171-176.

Halamski, A.T., and M.K. Zapalski. 2006. Les schistes à brachiopodes de Skaly-un niveau exceptionnel. Première partie: Inventaire faunistique. Bulletin mensuel de la Société linnéenne de Lyon 75(3): 145-150.

Havlíček, V. 1977. Brachiopods of the order Orthida in Czechoslovakia. Rozpravy Ústrédnıho Ústavu Geologického 44:1-327, pls I-LXVI.

Hubert, B.L.M., M.K. Zapalski, J.-P. Nicollin, B. Mistiaen, and D. Brice. 2007. Selected benthic faunas from the Devonian of the Ardennes: An estimation of palaeobiodiversity. Acta Geologica Polonica 57(2): 223-262.

Imbrie, J. 1959. Brachiopods of the traverse group (Devonian) of Michigan. Part 1: Dalmanellacea, Pentameracea, Strophomenacea,
Orthotetacea, Chonetacea, and Productacea. Bulletin of the American Museum of Natural History 116(4): 349-409, pls 18-67.

Jansen, U. 2001. Morphologie, Taxonomie und Phylogenie unterdevonischer Brachiopoden aus der Dra-Ebene (Marokko, PräSahara) und dem Rheinischen Schiefergebirge (Deutschland). Abhandlungen der senckenbergischen naturforschenden Gesellschaft 554: 1-389, pls 1-34.

von Kelus, A. 1939. Devonische Brachiopoden und Korallen der Umgebung von Pełcza in Volhynien. Bulletin du Service géologique de Pologne 8: 1-51, pls I-III.

King, W. 1850. The Permian fossils of England. Monograph of the Palaeontographical Society of London 37: 1-253, pls 1-29.

Kozłowski, R. 1929. Les brachiopodes gothlandiens de la Podolie polonaise. Palaeontologia Polonica 1: 1-254, pls I-XII.

Krawczyński, C. 2008. The Upper Oxfordian (Jurassic) thecideide brachiopods from the Kujawy area, Poland. Acta Geologica Polonica 58(4): 395-406.

Leidhold, C. 1925. Die systematische Bedeutung der Schalenporenweite bei fossilen articulaten Brachiopoden, erlautert an devonischen Orthiden. Centralblatt für Mineralogie, Geologie und Paläontologie, B 7: 223-228.

Ljaschenko, A.I. 1959. Atlas brachiopod $i$ stratigrafiá devonskih otloženij centralnyh oblastej russkoj platformy, 451, pls 1-87. Moskva: Gosgeoltehizdat.

Łobanowski, H. 1971. The Lower Devonian in the western part of the Klonów Belt (Holy Cross Mts.) Part I-Upper Emsian. Acta Geologica Polonica 21(4): 629-687, pls 13-32.

Malec, J. 1999. Profil litologiczny i zróżnicowanie facjalne osadów dewonu środkowego w regionie łysogórskim Gór Świętokrzyskich. Posiedzenia naukowe Państwowego Instytutu Geologicznego 55: 149-151.

Małkowski, K. 1981. Upper Devonian deposits at Górno in the Holy Cross Mts. Acta Geologica Polonica 31(3-4): 223-232.

Meek, F.B. 1868. Remarks on the geology of the valley of Mackenzie River, with figures and descriptions of fossils from that region, in the Museum of the Smithsonian Institution, principally collected by the Late Robert Kennicott, Esq. Chicago Academy of Sciences, Transactions 1(3): 61-114, pls 11-15.

Mottequin, B. 2008. New observations on Upper Devonian Brachiopods from the Namur-Dinant Basin (Belgium). Geodiversitas 30(3): 455-537.

Nikiforova, O.I., T.L. Modzalevskaya, and M.G. Bassett. 1985. Review of the upper Silurian and lower Devonian articulate Brachiopods of Podolia. Special Papers in Palaeontology 34: $1-66$, pls $1-16$.

Pajchlowa, M. (1957). The Devonian in the Grzegorzowice-Skały section. Biuletyn Instytutu Geologicznego 122: 145-254.

Pérez-Huerta, A., M. Cusack, S. McDonald, F. Marone, M. Stampanoni, and S. MacKay. 2009. Brachiopod punctae: A complexity in shell biomineralisation. Journal of Structural Biology 167: 62-67.

Plezia, M. (ed.). 1959. Stownik tacińsko-polski. Tom IV: P-R, 583. Warszawa: Państwowe Wydawnictwo Naukowe.

Pocock, Y.P. 1966. Devonian Schizophoriid Brachiopods from Western Europe. Palaeontology 9(3): 381-412.

Racki, G. 1993a. Evolution of the bank to reef complex in the Devonian of the Holy Cross Mountains. Acta Palaeontologica Polonica 37(2/4): 87-182.

Racki, G. 1993b. Brachiopod assemblages in the Devonian Kowala Formation of the Holy Cross Mountains. Acta Paleontologica Polonica 37(2/4): 255-289.

Racki, G. 2005. Annotations to the Devonian Correlation Table, R220-227 di-ds 05: Devonian of Poland. Senckenbergiana Lethaea 85(1): 189-190.

Rudwick, M.J.S. 1970. Living and fossil Brachiopods, 199. London: Hutchinson University Library. 
Ruggiero, E.T. 1983. Struttura del guscio dei generi Gryphus e Terebratula (Terebratulidae, Brachiopoda). Bollettino della Società dei Naturalisti in Napoli 90: 177-201, pls I-VIII.

Ruggiero, E.T. 1987. Megathyrididae (Brachiopoda) attuali raccolti lungo le coste della Campania e della Puglia. Bollettino della Società dei Naturalisti in Napoli 94: 255-285, pls I-VII.

Samsonowicz, J. 1950. The Devonian in Volhynia. Acta Geologica Polonica 1(4): 401-519, pls I-II.

Samsonowicz, J. 1966. Mapa geologiczna Gór Świętokrzyskich. In Przewodnik do ćwiczen' z geologii dynamicznej. Wydanie drugie, ed. W. Jaroszewski, 237. Warszawa: Wydawnictwa Geologiczne.

Schuchert, C., and G.A. Cooper. 1931. Synopsis of the brachiopod genera of the suborders Orthoidea and Pentameroidea, with notes on the Telotremata. American Journal of Science 22: 241-251.

Schuchert, C., and G.A. Cooper. 1932. Brachiopod Genera of the Suborders Orthoidea and Pentameroidea. Memoirs of the Peabody Museum of Natural History 4(1): 1-270.

Schuchert, C., and C.M. LeVene. 1929. New names for brachiopod homonyms. American Journal of Science 17: 119-122.

Shimer, H.W., and R.R. Shrock. 1944. Index fossils of North America. A new work based on the complete revision and reillustration of Grabau and Shimer's “North American index Fossils”, 837. Cambridge, Massachusetts: The M.I.T. Press.

Stigall Rode, A.L. 2005. Systematic revision of the middle and late Devonian Brachiopods Schizophoria (Schizophoria) and "Schuchertella" from North America. Journal of Systematic Palaeontology 3: 133-167.

Struve, W. 1963. Schizophoria pygmaea n.sp. Senckenbergiana lethaea 44(3): 251-263, pls 39-40.
Struve, W. 1965. Schizophoria striatula und Schizophoria excisa in ihrer ursprünglichen Bedeutung. Senckenbergiana lethaea 46(2/3): 193-215, pls 19-21.

Struve, W. 1992. Neues zur Stratigraphie und Fauna des rhenotypen Mittel-Devon. Senckenbergiana lethaea 71(5/6): 503-624.

Stupnicka, E. 1992. The significance of the Variscan orogeny in the Świętokrzyskie Mountains (Mid Polish Uplands). Geologische Rundschau 81(2): 561-570.

Wang, Y. 1956. Some new brachiopods from the Yükiang Formation of Southern Kwangsi Province. Scientia Sinica 5: 373-388, pls I-III.

Williams, A. 1997. Shell structure. In Treatise on Invertebrate Paleontology. Part H: Brachiopoda, revised. Volume 1: Introduction, eds. A. Williams, C.H.C. Brunton, and S.J. Carslon, $\mathrm{xx}+539$ pp. Boulder, Colorado, and Lawrence, Kansas: The Geological Society of America, Inc. and The University of Kansas.

Williams, A., and C.H.C. Brunton. 1997. Morphological and anatomical terms applied to brachiopods. In Treatise on Invertebrate Paleontology. Part H: Brachiopoda, revised. Volume 1: Introduction, eds. A. Williams, C.H.C. Brunton, and S.J. Carslon, $\mathrm{xx}+539$ pp. Boulder, Colorado, and Lawrence, Kansas: The Geological Society of America, Inc. and The University of Kansas.

Williams, A., S.J. Carlson, C.H.C. Brunton, L.E. Holmer, and L. Popov. 1996. A supra-ordinal classification of the Brachiopoda. Philosophical Transactions of the Royal Society London, B 351: 1171-1193.

Zapalski, M.K. 2005. Paleoecology of Auloporida: An example from the Devonian of the Holy Cross Mts., Poland. Géobios 38(5): 677-683. 